\title{
QUANTITATIVE CHARACTERISTICS OF COLISEUM MAPLE (ACER CAPPADOCICUM GLED. 1785) IN RELATION TO PHYSIOGRAPHIC FACTORS IN HYRCANIAN FORESTS OF IRAN (CASE STUDY: SANGDEH, MAZANDARAN PROVINCE)
}

\author{
SHABANIVARAKI, $\mathrm{H} .^{1}-$ AlVANINEJAD, . $^{2 *}-$ ESPAHBODI, K. ${ }^{3}$ \\ ${ }^{I}$ Department of Forestry, Faculty of Agriculture, Yasouj University, Yasouj, Iran \\ e-mail: hojjat_shabani@ymail.com \\ ${ }^{2}$ Department of Forestry, Faculty of Agriculture and Institute of Natural Resources and \\ Environment, Yasouj University, Yasouj, Iran \\ ${ }^{3}$ Department of Natural Resources, Agriculture and Natural Resources Research and Education \\ Center of Mazandaran, Mazandaran, Sari, Iran \\ e-mail: espahbodi.k@gmail.com \\ *Corresponding author \\ e-mail: salvaninejad@yu.ac.ir; phone: +98-743-100-6063
}

(Received $4^{\text {th }}$ Feb 2017; accepted $28^{\text {th }}$ Mar 2017)

\begin{abstract}
The aim of this study was to investigate the effects of physiographic factors (altitude, slope and direction gradients) on quantitative characteristics of coliseum maple (Acer cappadocicum Gled. 1785) trees in Sangdeh, Mazandaran province. For this purpose, 93 sample plots of 0.1-hectare area each were laid out with a selective sampling method in different physiographic conditions, on the parts where the frequency of this species was high. Quantitative characteristics of coliseum maple trees in plots were recorded. To evaluate the group response of quantitative characteristics of coliseum maple trees to physiographic factors the multivariate analysis (RDA) was applied using Canoco Version 4.5. Results showed that the effects of physiographic factors on the quantitative characteristics of coliseum maple trees were significant. The correlation results demonstrated that with the increased of altitude, the characteristics as collar diameter, diameter at breast height, diameter at onset crown, total height, trunk length, trunk length to first branch, mean of crown diameter and crown length of coliseum maple trees, were significantly reduced. The highest values of diameter at breast height, collar diameter, diameter at onset crown, total height, and trunk length of maple were observed in the northwest aspect. The redundancy analysis (RDA) results showed that the quantitative characteristics of coliseum maple trees were located in the negative direction of the first axis and altitude had an inverse correlation with quantitative characteristics.
\end{abstract}

Keywords: Acer cappadocicum Gled., altitudinal gradient, north forests of Iran, redundancy analysis, silvicultural parameters, slope gradient

\section{Introduction}

The Hyrcanian forests with an area of 1.9 million hectares (Marvie-Mohadjer, 2005), is located in north of Iran in the provinces of Gilan, Mazandaran and Golestan (Moradi et al., 2012). This region is one of the diverse ecosystems of the temperate bioclimatic in the northern hemisphere, containing about 80 tree and 50 shrub species (Marvie-Mohadjer, 2005). Coliseum maple (Acer cappadocicum Gled. 1785) is one of the valuable tree species in these forests in the Sangdeh region, Mazandaran province. This species is found sporadically, individually, and mixed with beech (Fagus orientalis Lipsky), ChestnutLeaved oak (Quercus castaneifolia C.A. Mey.), hornbeam (Carpinus betulus L.), and velvet maple (Acer velutinum Boiss.) trees in forests of Golestan, Mazandaran and Gilan provinces as well as Arasbaran region (Sabeti, 2008; Mozafariyan, 2004). Knowledge of 
the characteristics, needs, and vegetative processes of trees and their interaction with habitat conditions are among the most important success factors for silviculture projects and forest management. Few studies have been conducted on quantitative and habitat characteristics of coliseum maple and the companion species in the Hyrcanian forests, including research conducted on wild service trees (Sorbus torminalis L. Crantz), ironwood tree (Parrotia persica C.A.Mey.), big-leaf linden (Tilia platyphyllos Scop.), cherry (Cerasus avium L.), ash (Fraxinus excelsior L.), and velvet maple. In a study carried out on soil characteristics and on the companion species of coliseum maple in nine habitats in the forests of western Mazandaran Province, it was reported that coliseum maple trees tolerated a wide range of $\mathrm{pH}(4.3-8.17)$. It was also mentioned that plants such as mercury (Mercurialis perennis L.), bedstraw (Galium odoratum L.), and violet (Viola odorata L.) were among the companion indicator species (Ramazani et al., 2000). The results of studies by Espahbodi et al. (2012) also indicated that 42 percent of wild service trees were observed in mixed stands of beech, hornbeam, and Chestnut-Leaved oak on the western slopes and 28 percent in pure beech forests on the northern slopes. Coliseum maple forms mixed forests with some broadleaf species in the central Himalayas (such as oak and alder) and coniferous species including fir (Abies sp.), and exhibits excellent shade tolerance (Rikhari et al., 1998). The results of research by Sefidi et al. (2011) on ironwood tree showed that the number of companion species varied between 3 and 16, of which the most important species were beech and hornbeam. Since very few studies have been carried out on quantitative characteristics of coliseum maple in related to physiographic factors in Iran, this research was aimed to study the effects of physiographic factors (slope, altitude, and directions) on some quantitative characteristics of this species. It should be mentioned that no report has been published so far in this regard in Iran.

\section{Materials and Methods}

\section{Materials}

\section{Study area}

This research was conducted in the forests managed by the Farim Wood Company located south of Sari (Fig. 1). These forests border - the rangelands and the Alborz Mountain Range to the south, the villages and agricultural lands to the north at altitudes of 500-700 meters above sea level (a.s.l), the forests managed by the Mazandaran Wood and Paper Company to the east, and the Savadkooh forests to the west. The altitude of these forests varies from 900 meters in the Farim Plain to 2700 meters on the slopes of the Alborz Mountains (Espahbodi et al., 2007). The study region lies between $53^{\circ} 8^{\prime} 15^{\prime \prime}$ and $53^{\circ} 27^{\prime}$ 22" East longitude and between $36^{\circ} 1^{\prime} 5^{\prime \prime}$ and $36^{\circ} 11^{\prime} 5^{\prime \prime}$ North latitude. Individual coliseum maple trees in this region were studied in the forest series of Dehmian, Sangdeh, Ashk, Boola, Partkola, Kaljkola, Resket, and Jourjadeh.

Twenty-year climate data from three meteorological stations in the region is presented in Table 1. Mean temperature at all three stations varied from $9^{\circ} \mathrm{C}$ at the highest station to $11.3^{\circ} \mathrm{C}$ at the lowest one (Espahbodi et al., 2012). The average temperature in the coldest month of the year varied from $-6.9^{\circ} \mathrm{C}$ at the altitude of 1550 meters to -6.4 at the altitude of 1200 meters. The maximum mean temperature increases from $23.5^{\circ} \mathrm{C}$ at the Orimelek station with the altitude of 1550 meters to $27.1^{\circ} \mathrm{C}$ at the Darzikola station with the altitude of 1200 meters. The average annual rainfall varied from 658.7 to 837.1 millimeters (Table 1). 


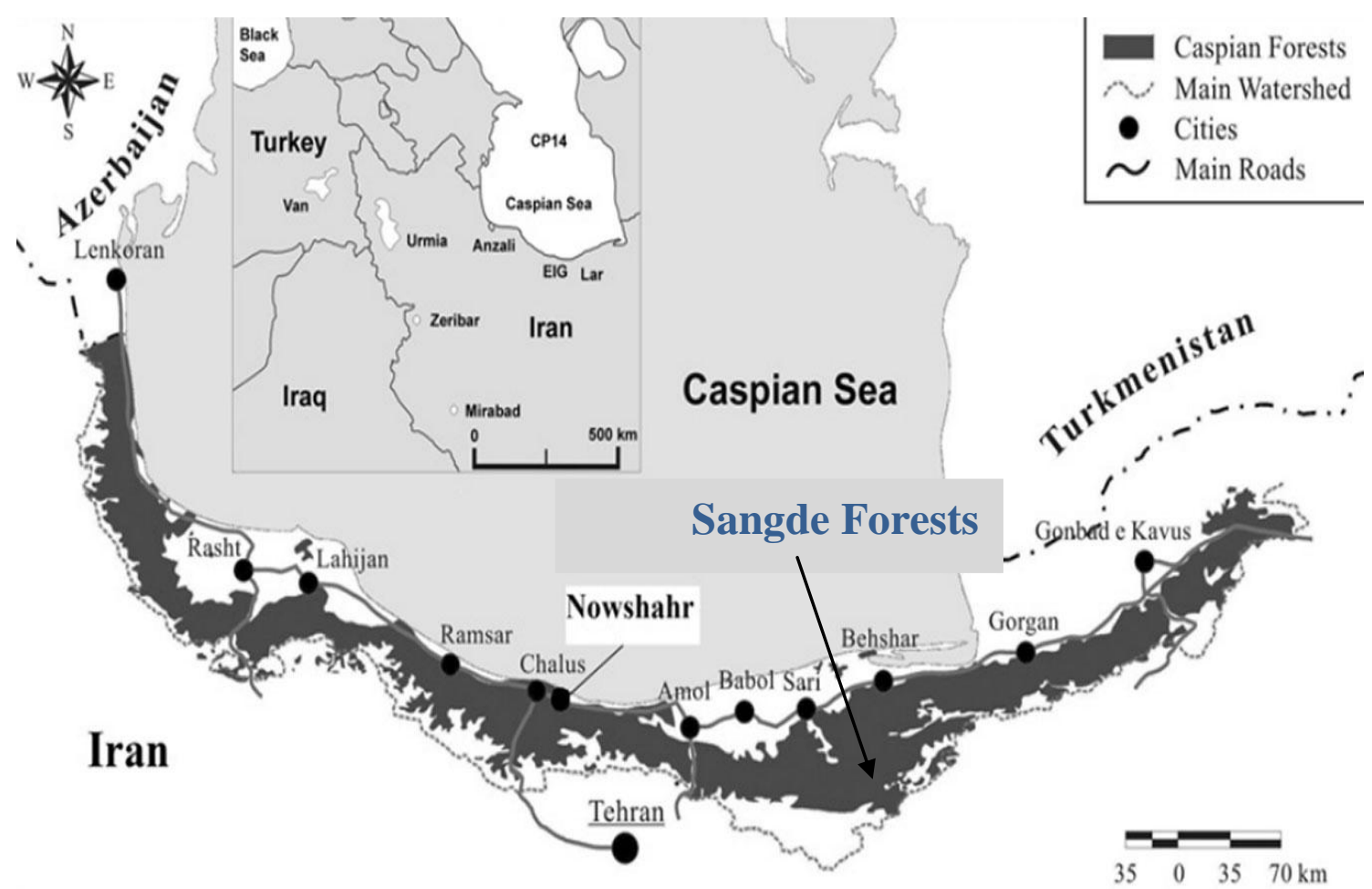

Figure 1. The distribution of Hyrcanian forests in Iran (Sefidi et al., 2011)

Table 1. Information of climate weather stations in the study area

\begin{tabular}{|c|c|c|c|c|c|c|}
\hline Station & Altitude & $\begin{array}{r}\text { Minimum of } \\
\text { Temperature } \\
\left({ }^{\circ} \mathrm{C}\right)\end{array}$ & $\begin{array}{r}\text { Maximum of } \\
\text { Temperature } \\
\left({ }^{\circ} \mathrm{C}\right)\end{array}$ & $\begin{array}{r}\text { Average of } \\
\text { Temperature } \\
\left({ }^{\circ} \mathrm{C}\right)\end{array}$ & $\begin{array}{r}\text { Average of } \\
\text { Precipitation } \\
(\mathbf{m m})\end{array}$ & $\begin{array}{r}\text { Average of } \\
\text { Evaporation } \\
(\mathbf{m m})\end{array}$ \\
\hline Darzikola & 1200 & -6.4 & 27.1 & 11.3 & 658.7 & 790.8 \\
\hline Sangdeh & 1350 & -5.3 & 25.4 & 10.8 & 837.1 & 766.1 \\
\hline Orimelek & 1550 & -6.9 & 23.5 & 9 & 821.3 & 738.3 \\
\hline
\end{tabular}

\section{Methods}

For this research, initially, the habitats of coliseum maple trees were identified in the region. This was carried out by studying the available silviculture projects, and using the experiences of experts, supervising the Farim Project, as well as forest excursions. Since coliseum maple trees were not present as pure stands in extensive areas, but rather were observed sporadically in various locations, the selective sampling method in 1000 $\mathrm{m}^{2}$ circular plots (with a diameter of 17.84 meters) was carried out. This method was used due to the low frequency of the coliseum maple in the region (Marvie-Mohadjer, 2005; Zobeyri, 2002; Babakhanjani-Shiraz et al., 2012). Considering that the study region consisted of several series, an attempt was made to make the sample plots scattered in all of the series and in various physiographic positions, covering almost the entire study region, so that the ecological and silvicultural conditions of this tree species could be properly studied. Since, based on studies mentioned in the booklet on forest projects in the region, coliseum maple trees were not present in all forest parcels and/or were not uniformly present in all parcels, wherever at least one coliseum maple tree was 
found, a 1000- $\mathrm{m}^{2}$ sample plot was selected. In total, 93 sample plots were selected and 360 coliseum maple trees were studied. In the sample plots, habitat characteristics were recorded using a Sonto slope- measuring device, an altimeter to measure altitude and a compass for determining directions by degrees and conversion using the Equation 1. In each sample plot, the number of individual coliseum maple trees and quantitative and qualitative characteristics including collar diameter, diameter at breast height, diameter at onset crown, total height, length of the trunk, length of the trunk to the first branch, length of the trunk to the first curvature, mean of crown diameter, and crown length were recorded.

$$
\text { Cos (Radians A) }+1, A=\text { The Azimuth of direction (degrees) }
$$

\section{Data analysis}

The collected data were analyzed using SPSS ver. 19. Data normality was firstly tested by the Kolmogorov-Smirnov test. Since the data were normal (normality test), the one-way ANOVA was employed to study the differences among the various classes of physiographic factors (altitude, slope and direction), and Duncan's test was used to compare the means. Moreover, Pearson's correlation coefficient was employed to study the correlations between quantitative characteristics of coliseum maple trees and physiographic factors. To evaluate the group response of quantitative characteristics of coliseum maple trees to physiographic factors (altitude, slope, and direction), the gradient length was calculated to be less than three using detrended correspondence analysis (DCA). Therefore, redundancy analysis (RDA) was applied in this study using Canoco Version 4.5.

\section{Results}

\section{Frequency of coliseum maple trees in the sample plots}

In this research, 93 sample plots were studied containing 360 individual coliseum maple trees in all. There were about four coliseum maple trees in each sample plot on average, with the minimum of one and maximum of 29 in each sample plot. There were $1,2,3,4,5$, and more than 6 coliseum maple trees in 17.2, 29, 18.3, 9.7, 8.6, and 17.2\% of the sample plots, respectively. The minimum collar diameter in the 360 studied trees in Sangdeh forests was 9 and the maximum 131 centimeters (Table 2). The mean diameter at breast height of coliseum maple trees was $29.38 \mathrm{~cm}$, maximum total height $41.8 \mathrm{~m}$, and the average total height of the studied trees $19.41 \mathrm{~m}$. The maximum length of the crown- in the studied trees was $20 \mathrm{~m}$, the mean trunk length $12.12 \mathrm{~m}$, the average crown length $8.60 \mathrm{~m}$, the mean trunk length to the first branch $8.24 \mathrm{~m}$, and the average trunk length to the first curvature $2.88 \mathrm{~m}$ (Table 2).

Table 2. Descriptive statistics of quantitative characteristics of coliseum maple trees

\begin{tabular}{ccccc}
\hline $\begin{array}{c}\text { Quantitative } \\
\text { Characteristics }\end{array}$ & Minimum & Maximum & Average & $\begin{array}{c}\text { Standard } \\
\text { Deviation }\end{array}$ \\
\hline Cd $(\mathbf{c m})$ & 9 & 131 & 38.6 & 21.68 \\
dbh $(\mathbf{c m})$ & 7.5 & 115 & 29.38 & 17.95 \\
doc $(\mathbf{c m})$ & 2.5 & 95 & 15.72 & 11.44 \\
\hline
\end{tabular}




\begin{tabular}{ccccc}
\hline th (m) & 5 & 41.8 & 19.41 & 7.1 \\
$\mathbf{l t}(\mathbf{m})$ & 1.8 & 30 & 12.12 & 5.44 \\
$\mathbf{l t f b}(\mathbf{m})$ & 0.4 & 23.5 & 8.24 & 4.35 \\
$\mathbf{l t f c}(\mathbf{m})$ & 0.5 & 17.3 & 2.88 & 2.64 \\
$\mathbf{m c d}(\mathbf{m})$ & 1.25 & 26 & 6.62 & 3.48 \\
$\mathbf{c l}(\mathbf{m})$ & 1.5 & 20 & 8.60 & 4.08 \\
\hline
\end{tabular}

$\mathrm{Cd}=$ collar diameter, $\mathrm{dbh}=$ diameter at breast height, $\mathrm{doc}=$ diameter at onset crown, $\mathrm{th}=$ total height, $\mathrm{lt}=$ length of the trunk, $1 \mathrm{tfb}=$ length of the trunk to the first branch, ltfc= length of the trunk to the first curvature, $\mathrm{mcd}=$ mean of crown diameter, $\mathrm{cl}=$ crown length

\section{Effects of aspect on quantitative characteristics of coliseum maple trees}

Results of ANOVA indicated that there were significant differences among various classes of directions for the quantitative characteristics including mean collar diameter, mean diameter at breast height, diameter at onset crown, total height, average crown diameter, and crown length. The various classes of directions had no significant effect on trunk length to the first curvature (Table 3). The results of mean comparisons, showed that the maximum values of collar diameter, diameter at onset crown, total height, and average crown diameter were recorded in the northwest direction and the maximum crown length in the southeast direction (Table 3).

\section{Effects of altitude on quantitative characteristics of coliseum maple trees}

Results of ANOVA showed that altitude had significant effects on the means of collar diameter, diameter at breast height, and diameter at onset crown, total height, trunk length, and on the means of crown diameter and length. However, its effects on trunk length before the first curvature were not significant (Table 4). Comparison of the means indicated that the maximum of the collar diameter, diameter at breast height, and diameter at onset crown were observed in the midlands (altitudes of 900-1101 m a.s.l) and the minimum in the highlands (altitudes of 2101-2300 $\mathrm{m}$ a.s.1). The minimum diameter at breast height was also recorded in the altitude range of 1300-1500 m a.s.l, and the maximum averages of total height, trunk length, and crown diameter and length belonged to the altitude ranging from 900 to $1100 \mathrm{~m}$ a.s.l.

Analysis of the correlations revealed that there was a positive correlation between slope and trunk length before the first curvature $(\mathrm{P}<0.05)$ (Table 6). Comparison of the means indicated that the maximum collar diameter, diameter at breast height, and diameter at onset crown were those of the lowlands (900-1101 $\mathrm{m}$ a.s.1) and the minimum were those of the highlands (2101-2300 $\mathrm{m}$ a.s.1) (Table 4), while the averages of total height, trunk length, and crown diameter and length were recorded in the lowlands. The results of correlation revealed that there were negative significant correlations between altitude and collar diameter, diameter at breast height, diameter at onset crown, total height, trunk length, and mean of crown diameter and length (Table 6). 
Table 3. Analysis variance and comparison of the mean (tstandard error) of quantitative characteristics of coliseum maple trees in direction classes (the number in parentheses in each classes of direction represent the number of plot)

\begin{tabular}{|c|c|c|c|c|c|c|c|c|c|c|}
\hline \multirow[b]{2}{*}{$\begin{array}{c}\text { Silviculture } \\
\text { Characteristics }\end{array}$} & \multirow[b]{2}{*}{$\mathbf{F}$} & \multirow[b]{2}{*}{$\begin{array}{l}P \\
\text { value }\end{array}$} & \multicolumn{7}{|c|}{ Direction Classes } & \multirow[b]{2}{*}{ Northwest(18) } \\
\hline & & & North (17) & Northeast(14) & East(17) & Southeast(6) & South(5) & Southwest(6) & West(10) & \\
\hline $\mathrm{Cd}(\mathrm{cm})$ & 2.42 & $0.02^{*}$ & $35.8(2.8) \mathrm{b}$ & $35.2(2.7) \mathrm{b}$ & $37.9(2) \mathrm{ab}$ & 44.08(4)ab & $35.5(4) b$ & 39.9(5.1)ab & $34.82(3.3) \mathrm{b}$ & $48.8(3.8) \mathrm{a}$ \\
\hline dbh (cm) & 3.78 & $0.001^{* *}$ & $28.5(2.4) b c$ & 26.1(2.2)bc & 27.2(1.4)bc & $35.4(3.4) \mathrm{ab}$ & $23.5(2.2) \mathrm{c}$ & $31.65(4.2) \mathrm{abc}$ & $26.74(2.7) b c$ & $39.5(3.3) \mathrm{a}$ \\
\hline $\operatorname{doc}(\mathrm{cm})$ & 2.74 & $0.009^{* *}$ & $14.7(1.6) \mathrm{b}$ & $13.4(1.3) \mathrm{b}$ & $14.8(0.8) \mathrm{b}$ & 18.56(1.6)ab & $17.2(3.1) \mathrm{ab}$ & $16.3(2.8) \mathrm{ab}$ & 13.1(1.9)b & $21.2(2.2) \mathrm{a}$ \\
\hline th (m) & 4.002 & $0.001^{* *}$ & $18.8(0.8) \mathrm{bcd}$ & $17.8(0.99) \mathrm{cd}$ & 19.3(0.6)bcd & 21.8(1.2)ab & $16.2(1.02) \mathrm{d}$ & 20.9(1.97)abc & $17.8(1.2) \mathrm{cd}$ & $23.17(1.14) \mathrm{a}$ \\
\hline lt(m) & 4.86 & $0.001^{* *}$ & $10.9(0.7) \mathrm{d}$ & $11.6(0.7) \mathrm{bcd}$ & $11.6(0.68) \mathrm{bcd}$ & $14.3(0.96) \mathrm{ab}$ & $10.33(0.56) \mathrm{d}$ & $13.8(1.8) \mathrm{abc}$ & 11.6(0.9)bcd & $15.4(0.9) \mathrm{a}$ \\
\hline ltfb (m) & 2.9 & $0.006^{* *}$ & $7.8(0.6) \mathrm{ab}$ & $6.74(0.82) b$ & $8.1(0.32) \mathrm{ab}$ & $10.15(0.73) \mathrm{a}$ & $6.53(0.72) b$ & $10.07(1.4) \mathrm{a}$ & $8.6(0.9) \mathrm{ab}$ & $9.9(1.03) \mathrm{a}$ \\
\hline ltfc (m) & 1.54 & $0.15^{\text {ns }}$ & $2.3(0.28) \mathrm{a}$ & $3.23(0.39) \mathrm{a}$ & $2.8(0.25) \mathrm{a}$ & $2.03(0.4) \mathrm{a}$ & $2.3(0.57) \mathrm{a}$ & $2.33(0.57) \mathrm{a}$ & $3.2(0.47) \mathrm{a}$ & $3.55(0.45) \mathrm{a}$ \\
\hline $\operatorname{mcd}(\mathbf{m})$ & 3.64 & $0.001^{* *}$ & $6.25(0.4) \mathrm{bcd}$ & $5.99(0.4) \mathrm{cd}$ & $6.4(0.3) \mathrm{bcd}$ & 7.8(0.6)abc & $5.34(0.45) \mathrm{d}$ & $8.04(1.05) \mathrm{ab}$ & $5.97(0.52) \mathrm{cd}$ & $8.3(0.65) \mathrm{a}$ \\
\hline $\mathbf{c l}(\mathbf{m})$ & 3.7 & $0.001^{* *}$ & $8.28(0.54) \mathrm{cd}$ & $7.5(0.56) \mathrm{d}$ & $8.16(0.34) \mathrm{cd}$ & $10.6(0.72) \mathrm{a}$ & $8.45(0.8)$ bcd & $9.75(1.01) \mathrm{abc}$ & $7.8(0.8) \mathrm{cd}$ & $10.5(0.56) \mathrm{ab}$ \\
\hline
\end{tabular}

** Significant correlation level $\mathrm{p}<0.01$, * Significant correlation level $\mathrm{p}<0.05$ and ns not significant. Similar letters showed no significant difference between the rows.

Table 4. Analysis variance and comparison of the mean (土standard error) of quantitative characteristics of coliseum maple trees in altitude classes (the number in parentheses in each classes of altitude represent the number of plot)

\begin{tabular}{|c|c|c|c|c|c|c|c|c|c|}
\hline \multirow[b]{2}{*}{$\begin{array}{c}\text { Silviculture } \\
\text { Characteristics }\end{array}$} & \multirow[b]{2}{*}{$\mathbf{F}$} & \multirow[b]{2}{*}{$P$ value } & \multicolumn{7}{|c|}{ Altitude Classes (m a.s.l.) } \\
\hline & & & $900-1101(5)$ & 1101-1300(12) & 1301-1500(12) & $1501-1700(23)$ & 1701-1900(19) & $1901-2100(17)$ & $2101-2300(5)$ \\
\hline $\mathrm{Cd}(\mathrm{cm})$ & 10.04 & $<0.01^{* *}$ & 73.8(12.2)a & $47.7(3.7) b$ & $32.8(1.6) \mathrm{c}$ & 35.84(1.8)ab & $46.85(3.2) \mathrm{b}$ & $34.64(2.8) \mathrm{c}$ & $23.9(4.4) \mathrm{c}$ \\
\hline dbh (cm) & 12.8 & $<0.01^{* *}$ & $63.8(11.6) \mathrm{a}$ & $37.6(3) b$ & $23.7(1.4) \mathrm{d}$ & 26.9(1.4)ab & $36.05(2.5) b c$ & $26.3(2.2) \mathrm{ab}$ & $17.7(3.4) \mathrm{d}$ \\
\hline $\operatorname{doc}(\mathrm{cm})$ & 11.2 & $<0.01^{* *}$ & $40.56(10) a$ & $20.2(1.8) b$ & 13.3(0.9)ab & $15.06(1.1) b c$ & $17.3(1.2) \mathrm{bc}$ & 13.2(1.3)ab & $8.18(1.1) \mathrm{d}$ \\
\hline th (m) & 4.9 & $<0.01^{* *}$ & $22.9(2.3) \mathrm{a}$ & $22.25(1.12) \mathrm{a}$ & $17.96(0.64) b$ & $19.5(0.72) \mathrm{ab}$ & 21.4(0.9)ab & $17.75(1.06) \mathrm{b}$ & $13.64(1.6) \mathrm{c}$ \\
\hline $\mathbf{l t}(\mathbf{m})$ & 4.88 & $<0.01^{* *}$ & $15.08(1.87) \mathrm{a}$ & 14.6(0.9)a & $10.65(0.5) \mathrm{bc}$ & $12.34(0.56) \mathrm{ab}$ & $13.3(0.64) \mathrm{ab}$ & $11.03(0.75) b c$ & $8.8(0.99) \mathrm{c}$ \\
\hline ltfb (m) & 1.98 & $0.068^{\mathrm{ns}}$ & $10.26(1.9) \mathrm{a}$ & $9.9(0.8) \mathrm{a}$ & $7.4(0.56) \mathrm{a}$ & $8.75(0.48) \mathrm{a}$ & $7.5(0.56) \mathrm{a}$ & 8.3(0.67)a & $6.85(0.76) \mathrm{a}$ \\
\hline Itfc (m) & 0.78 & $0.58^{\mathrm{ns}}$ & $4.18(1.18) \mathrm{a}$ & $2.9(0.37) \mathrm{a}$ & $2.48(0.23) \mathrm{a}$ & $3.14(0.3) \mathrm{a}$ & $3(0.36) \mathrm{a}$ & $2.9(0.42) \mathrm{a}$ & $2.75(0.68) \mathrm{a}$ \\
\hline $\operatorname{mcd}(\mathbf{m})$ & 10.34 & $<0.01^{* *}$ & $12.96(2.62) \mathrm{a}$ & $8.55(0.6) b$ & $5.9(0.3) \mathrm{cd}$ & $6.17(0.3) \mathrm{cd}$ & $7.08(0.35) b c$ & $6.07(0.44) \mathrm{cd}$ & $4.22(0.68) \mathrm{d}$ \\
\hline cl (m) & 8.4 & $<0.01^{* *}$ & $13.4(1.35) \mathrm{a}$ & $11.05(0.66) \mathrm{b}$ & $8.27(0.36) \mathrm{c}$ & $8.3(0.42) \mathrm{c}$ & $9.08(0.5) \mathrm{bc}$ & $7.11(0.5) \mathrm{cd}$ & $4.96(0.72) \mathrm{d}$ \\
\hline
\end{tabular}

** Significant correlation level $\mathrm{p}<0.01$, Significant correlation level $\mathrm{p}<0.05$ and ns not significant. Similar letters showed no significant difference between the rows. 


\section{Effects of slope on quantitative characteristics of coliseum maple trees}

Results of ANOVA indicated that the effects of slope on diameter at onset crown, trunk length, trunk length before the first branch, and trunk length before the first curvature were significant (Table 5). The comparison of the means showed that the maximum diameter at onset crown was observed in the slope class of $61-80 \%$. Moreover, the maximum of trunk length belonged to the slope class of $41-60 \%$, and the largest values of trunk length before the first branch and trunk length before the first curvature were recorded for the slope class of 41-60\% and 81-150\% (Table 5). Furthermore, the effects of slope on collar diameter, diameter at breast height, total height, and on averages of crown diameter and length were not significant (Table 5).

Table 5. Analysis variance and comparison of the mean ( \pm standard error) of quantitative characteristics of coliseum maple trees in slope classes (the number in parentheses in each classes of slope represent the number of plot)

\begin{tabular}{|c|c|c|c|c|c|c|c|}
\hline \multirow[b]{2}{*}{$\begin{array}{c}\text { Quantitative } \\
\text { Characteristics }\end{array}$} & \multirow[b]{2}{*}{$\mathbf{F}$} & \multirow[b]{2}{*}{$\begin{array}{l}P \\
\text { Value }\end{array}$} & \multicolumn{5}{|c|}{ Slope Classes (\%) } \\
\hline & & & $1-20(18)$ & $21-40(23)$ & $41-60(24)$ & 61-80(18) & 81-150(10) \\
\hline $\mathrm{Cd}(\mathrm{cm})$ & 1.2 & $0.31^{\mathrm{ns}}$ & $39.15(2.8) \mathrm{a}$ & $36.8(1.8) \mathrm{a}$ & $39.5(2.3) \mathrm{a}$ & $42.1(3) \mathrm{a}$ & $33.37(3.2) \mathrm{a}$ \\
\hline dbh (cm) & 1.5 & $0.2^{\mathrm{ns}}$ & $29.8(2.2) \mathrm{a}$ & $26.8(1.5) \mathrm{a}$ & $30.9(1.9) \mathrm{a}$ & $32.24(2.6) \mathrm{a}$ & $25.8(2.7) \mathrm{a}$ \\
\hline $\operatorname{doc}(\mathrm{cm})$ & 2.64 & $0.034^{*}$ & $16.6(1.3) \mathrm{ab}$ & $13.22(0.7) b$ & 15.32(1)ab & $18.7(1.8) \mathrm{a}$ & $15.7(2.4) \mathrm{ab}$ \\
\hline th (m) & 2.2 & $0.068^{\mathrm{ns}}$ & $19.5(0.86) \mathrm{a}$ & $19.16(0.51) \mathrm{a}$ & $20.76(0.8) \mathrm{a}$ & $19.35(0.93) \mathrm{a}$ & 16.53(1.46)a \\
\hline $\operatorname{lt}(\mathbf{m})$ & 2.65 & $0.033^{*}$ & $11.05(0.64) \mathrm{b}$ & 11.44(0.4)ab & $13.4(0.62) \mathrm{a}$ & $12.7(0.68) \mathrm{ab}$ & $11.5(1.08) \mathrm{ab}$ \\
\hline ltfb (m) & 3.96 & $0.004^{* *}$ & 7.95(0.47)ab & $8.2(0.38) \mathrm{ab}$ & $9.8(0.6) \mathrm{a}$ & $6.76(0.7) \mathrm{b}$ & $8.97(0.96) \mathrm{a}$ \\
\hline $\operatorname{ltfc}(\mathrm{m})$ & 2.83 & $0.025^{*}$ & $2.25(0.24) \mathrm{b}$ & $2.44(0.24) \mathrm{ab}$ & $3.33(0.28) \mathrm{a}$ & $3.26(0.38) \mathrm{ab}$ & $3.43(0.6) \mathrm{a}$ \\
\hline $\operatorname{mcd}(\mathbf{m})$ & 1.7 & $0.14^{\mathrm{ns}}$ & $6.9(0.42) \mathrm{a}$ & $6.07(0.25) \mathrm{a}$ & $6.7(0.4) \mathrm{a}$ & 7.35(0.48)a & $5.8(0.64) \mathrm{a}$ \\
\hline cl (m) & 2.06 & $0.085^{\mathrm{ns}}$ & $8.53(0.5) \mathrm{a}$ & 8.67(0.36)a & $8.44(0.44) \mathrm{a}$ & $9.38(0.5) \mathrm{a}$ & $7.2(0.73) \mathrm{a}$ \\
\hline
\end{tabular}

** Significant correlation level $\mathrm{p}<0.01$, * Significant correlation level $\mathrm{p}<0.05$ and ns not significant, Similar letters showed no significant difference between the rows.

\section{Effects of physiographic factors on quantitative characteristics of coliseum maple trees}

The redundancy analysis (RDA) results showed that the physiographic factors had a significant effect on the quantitative characteristics of coliseum maple trees $(F=4.7$, $p=0.005$ ). The quantitative characteristics including collar diameter, diameter at breast height, diameter at onset crown, total height, length of the trunk, length of the trunk to the first branch, mean of crown diameter and crown length were located in the negative direction of the first axis and altitude had an inverse correlation with these characteristics. However, these traits were less affected by the slope and aspect (direction) and only length of the trunk to the first curvature was correlated with aspect (Figure 2). 


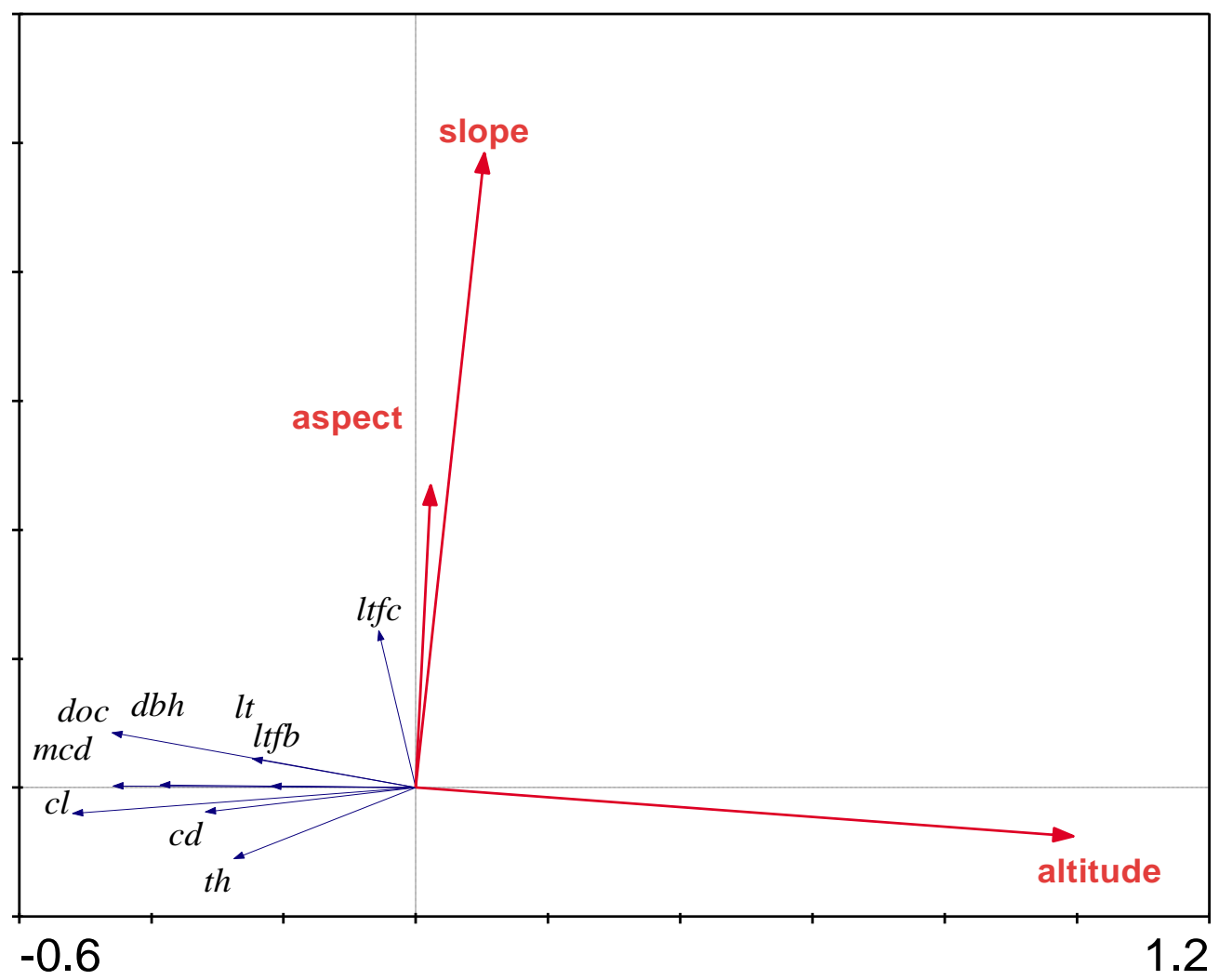

Figure 2. Bi-plot of quantitative characteristics of coliseum maple trees and physiographic factors (altitude, slope and aspect) in Redundancy Analysis (RDA) $(F=4.7, p=0.005) . C d=$ collar diameter, dbh= diameter at breast height, doc= diameter at onset crown, th=total height, lt= length of the trunk, ltfb= length of the trunk to the first branch, ltfc=length of the trunk to the first curvature, $m c d=$ mean of crown diameter, $c l=$ crown length

\section{Discussion}

The effects of physiographic factors (altitude, slope and aspect gradient) on various quantitative characteristics of coliseum maple trees (Acer cappadocicum Gled. 1785) were studied in the Sangdeh forests, north of Iran. According to the obtained results in this research, the averages of diameter at breast height and total height of coliseum maple trees were 29.38 centimeters and 19.41 meters, respectively. This shows that, the studied individual coliseum maple trees were relatively young and in the young-tomiddle-age stage (Table 2). Considering the silvicultural system, implemented during the past decades, based on even-aged management of beech, the removal of coliseum maple trees through the first cuttings of canopy shelter wood together with removing other species in favor of beech, may have been contributed to the problem. Moreover, since coliseum maple is a light- demanding species, it is observed in pure beech stands as individual trees. The light demanding characteristic of coliseum maple trees may result in their competition with beech stands for light, leading to increased height. In the present research, in young beech stands, the individual coliseum maple trees were observed even in the upper storey. Espahbodi et al. (2012) reported similar results in their silvicultural ecological study on wild service trees in Sangdeh. If a lightdemanding tree does not face competition, its diameter at breast height will increase more than its height. Species such as chestnut-Leaved oak, Caucasian wingnut 
(Pterocarya fraxinifolia (Lam.) Spach.) and hornbeam behave in the same way in lowland forests under non-competitive conditions.

ANOVA showed that the different classes of direction (aspect) had significant effects on some quantitative traits of coliseum maple trees (Table 3). Usually, in the north to east direction moisture is higher than in the north to west direction. The better light conditions cause the composition of the established stands to shift towards lightdemanding species. Under such conditions, both the competitive pressure for shadetolerant species such as beech is decreased and light conditions for growth and development of coliseum maple trees (especially for diameter growth) is improved. This can be the reason for observing coliseum maple trees with larger dimensions in the northwest direction. Moreover, it could indicate that coliseum maple trees are moisturedemanding trees, but because they cannot compete with shade-tolerant species, they are more frequently seen in the stony and warm places in the southern direction where shade-tolerant species are less frequently observed. However, they enjoy good growth in the northwest direction which has desirable moisture content. This is confirmed by reports that coliseum maple is among the species having low competitive power, so that in north forests of Iran, we always observe seedlings of coliseum maple trees but rarely find large trees of this species (Marvie-Mohadjer, 2005; Sadati and Mostafanejad, 2009). Hassanzad Navoroodi et al. (2000) studied the effects of slope direction on the numbers and standing volume of beech trees in Asalem, located in Gilan Province, and reported that the north, west, east, and northwest directions had greater standing volume, while the northeast direction had an average standing volume. Sharafieh and Sagheb-Talebi (2012), also studied some silvicultural and habitat characteristics of Quercus macranthera Fisch. Et Mey. in Semnan Province and reported that the tallest trees (23 meters) were in a flat region and the thickest (with a diameter of 255 centimeters) was on the north slope, while the largest volume of a single tree (19.81 silve) was measured on the north slope.

Results of correlations indicated that there was a significant negative correlation between altitude and collar diameter, diameter at breast height, diameter at onset crown, total height, trunk length, and averages of crown length and diameter (Table 6), also the redundancy analysis (RDA) results showed that altitude had an inverse correlation with these characteristics (Fig. 2). The summing up of these results indicates that the best individual coliseum maple trees were found where the altitude ranged from 900-1100 m a.s.l. Based on the climatic information of the meteorological station in Darzikola District with an altitude of $1200 \mathrm{~m}$ a.s.l, the coliseum maple trees are of the best qualitative and quantitative states in areas with the 30-year absolute minimum and maximum temperatures of -6.4 and $27.1^{\circ} \mathrm{C}$, respectively. Moreover, in these areas, the average annual temperature is $11.3^{\circ} \mathrm{C}$, and the mean rainfall and evaporation are 658.7 and 790.8 millimeters, respectively. This shows that the mean monthly temperature is the most limiting climatic factor for coliseum maple trees under the habitat conditions of Sangdeh. Comparison of the average temperatures at the two meteorological stations mentioned in Table 1 indicates that there is a drop of $3^{\circ} \mathrm{C}$ in temperature caused by an altitude change of $300 \mathrm{~m}$ a.s.l. Therefore, it seems that at altitudes of higher than 2000 $\mathrm{m}$ a.s.l the average monthly temperature is below $5^{\circ} \mathrm{C}$. Consequently, in areas with high altitudes, coliseum maple trees have smaller diameters, heights, and crowns compared to areas with lower altitudes because of the harsher environmental conditions such as temperature and type of precipitation. In a study carried out in the high mountainous regions of the Himalayas, it was also reported that coliseum maple trees at the altitude 
of 2750 meters were observed in wet clay or loam textured soils, and that the biomass decreased with increasing altitude (Garkoti and Singh, 1995). In many studies have been reported significant negative correlation between altitudinal gradient with photosynthesis and growth parameters (e.g. Cabrera et al., 1998; Rada et al., 1998; Zhang et al., 2005). Hassanzad Navroodi et al. (2015) have reported that variations with altitudes may have a higher impact than slopes on the quantitative characteristics of the Persian oak (Quercus persica) stand in Ilam province. Therefore, we can say that coliseum maple trees have larger diameters and crowns and are taller at altitudes of 900$1100 \mathrm{~m}$ a.s.l because of the suitable environmental conditions such as temperature. Of course, these conditions do not apply to all species. For example, Monfared et al. (2009) reported in their study on the qualitative and quantitative characteristics of Tilia platyphyllos Stev. trees in Gorgan that there were no significant differences between the habitats with respect to total height, length of the trunk before the first branch, and the height at which the crown started. However, they were significantly different in diameter at breast height, and the height at which the first branch started.

Table 6. Results of Pearson correlation between quantitative characteristics of coliseum maple trees with physiographic factors

\begin{tabular}{|c|c|c|c|}
\hline \multirow{2}{*}{$\begin{array}{c}\text { Quantitative } \\
\text { Characteristics }\end{array}$} & \multicolumn{3}{|c|}{ Physiographic Factors } \\
\hline & Slope & Altitude & Direction \\
\hline $\mathrm{Cd}(\mathrm{cm})$ & $-0.02^{\mathrm{ns}}$ & $-0.35^{* *}$ & $0.13^{\mathrm{ns}}$ \\
\hline dbh (cm) & $-0.001^{\mathrm{ns}}$ & $-0.36^{* *}$ & $0.17^{\mathrm{ns}}$ \\
\hline $\operatorname{doc}(\mathbf{c m})$ & $0.06^{\mathrm{ns}}$ & $-0.45^{* *}$ & $0.15^{\mathrm{ns}}$ \\
\hline th $(\mathbf{m})$ & $-0.09^{\text {ns }}$ & $-0.22^{*}$ & $0.11^{\mathrm{ns}}$ \\
\hline $\operatorname{lt}(\mathrm{m})$ & $0.06^{\mathrm{ns}}$ & $-0.21^{*}$ & $0.01^{\mathrm{ns}}$ \\
\hline ltfb (m) & $-0.006^{\mathrm{ns}}$ & $-0.18^{\mathrm{ns}}$ & $0.03^{\mathrm{ns}}$ \\
\hline Itfc (m) & $0.26^{*}$ & $-0.09^{\mathrm{ns}}$ & $0.08^{\mathrm{ns}}$ \\
\hline $\operatorname{mcd}(\mathbf{m})$ & $-0.005^{\mathrm{ns}}$ & $-0.43^{* *}$ & $0.13^{\mathrm{ns}}$ \\
\hline cl (m) & $-0.07^{\mathrm{ns}}$ & $-0.47^{* *}$ & $0.05^{\mathrm{ns}}$ \\
\hline
\end{tabular}

Results also revealed that the effects of slope on diameter at onset crown, trunk length, length of the trunk before the first branch (bifurcation), and length of the trunk before the first curvature were significant (Table 5). It must be mentioned that the length of trunk before the first branch is important in that two three-meter lengths of trunks are considered in the qualitative evaluation of industrial trunks. If the trunk length at the beginning of bifurcation is more than six meters the quality of the trunk improves. However, the shorter the length of the trunk before the first curvature is, the better the quality of the trunk will be because wood loss will decrease. Industrially, these two characteristics are more important compared to the others. Moreover, slope did not have significant effects on collar diameter, diameter at breast height, total height, crown length and diameter (Table 5). Therefore, it can be concluded that different slopes did not affect the important vegetative characteristics of coliseum maple trees, although the maximum trunk length was observed in the slope class of 41-60 percent. According to Espahbodi et al. (2012), the wild service trees established on lands with steep slopes had significantly lower dimensions than those on lands with gentler slopes. Moreover, the trunk length before the first curvature was shorter in trees 
established in areas with steep slopes. Furthermore, Pourmajidian and Moradi (2009) reported that there was a significant correlation between slope and number of trees per hectare, diameter at breast height, crown diameter, crown cover percentage, and number of Juniper tree (Juniperus polycarpus L.). This was an inverse correlation for some characteristics such as diameter and trunk height but a direct one for other characteristics including crown length and diameter.

\section{Conclusion}

In general, results of this research showed that quantitative characteristics of coliseum maple trees (collar diameter, diameter at breast height, diameter at onset crown, total height, length of the trunk, length of the trunk to the first branch, length of the trunk to the first curvature, mean of crown diameter, crown length) differed in various classes of altitude, slope, and direction. The important point is that in some classes of the physiographic factors (including south and northeast aspects) in which the frequency of coliseum maple trees are more, the average values of the parameters of collar diameter, diameter at breast height, total height, trunk length, trunk length to the first branch, and crown diameter and length are lower compared to other directions. This confirms that the frequency of individual coliseum maple trees in these directions has an inverse relationship with the ecological needs of these trees, which results from the pressure of competition with other species. In research by Espahbodi et al. (2007) it was also reported that the best individual wild service trees were observed in deep soils with the lowest frequency of these trees; however, the most individual wild service trees, with mean diameters and heights lower than average, were found in shallow soils (together with Chestnut-Leaved oak) on the west slopes.

\section{REFERENCES}

[1] Babakhanjani-Shiraz, B., Sagheb-Talebi, Kh., Hemmati, A. (2012): Ecological and silvicultural characteristics of cherry (Cerasusavium L.) in Guilan province. - Iranian Journal of Forest 4 (4): 365-376.

[2] Cabrera, H.M., Rada, F., Cavieres, L. (1998): Effects of temperature on photosynthesis of two morphologically contrasting plant species along an altitudinal gradient in the tropical high Andes. -Oecologia 114: 145-152.

[3] Espahbodi, K., Amani, M., Mohammadnejad Kiasari, Sh., Zare, H., Jafari Gorzin B., Chabok, A., Ehteshamadeh, M. (2007): Distribution of wild service tree based on some ecological factors in Sangdeh forests, North of Iran. -Iranian Journal of Forest and Poplar Research 15 (3): 207-216.

[4] Espahbodi, K., Mohammadnejad-Kiasari, Sh., Khorankeh, S., Mostafanejad, S.R. (2012): Investigation on distribution and some silvicultural characteristics of wild service tree (Sorbus torminalis) in Sangdeh Forest. -Iranian Journal of Forest and Poplar Research 20 (1): 11-24.

[5] Hassanzad Navroodi, I., Namiranian, M., Marvie-Mohadjer, M.R. Azizi, P. (2000): The effect of aspect and altitude on the volume of natural beech forests of Asalem. -Iranian Journal of Natural Resources 53(3): 201-215.

[6] Hassanzad Navroodi, I., Zarkami, R., Basati, M., Mohammadi Limaei, S. (2015): Quantitative and qualitative characteristics of Persian oak along altitudinal gradation and gradient (case study: Ilam province, Iran). -Journal of Forest Science 61 (7): 297-305. 
[7] Garkoti, S.C., Singh, S.P. (1995): Variation in net primary productivity and biomass of forests in the high mountains of Central Himalaya. Department of Botany, Kumaum University, India. -Journal of Vegetation Science 6: 23-28.

[8] Marvie-Mohadjer, M.R. (2005): Silviculture. -Second Edition, published by Tehran University.

[9] Monfared, A., Ghorbanali, M., Mirhoseanishahkohi, S.A. Niakan, M. (2009): The study of qualitative and quantitative traits and plant regeneration of Tilia platyphyllos in the forests of Gorgan. -Journal of plants and ecosystems, 5 (17): 2-18.

[10] Moradi, M., Marvi mohadjer, M.R., Sefidi, K., Zobeiri, M., Omidi, A. (2012). Overmature beech trees (Fagus orientalis Lipsky) and close-to-nature forestry in northern Iran. Journal of Forestry Research 23 (2): 289-294.

[11] Mozafariyan, V. (2004): Trees and Shrubs of Iran. -publishing contemporary culture.

[12] Pourmajidian, M.R., Moradi, M. (2009): Investigation on the site and silvicultural properties of Juniperus excelsa in natural forests of Ilan in Qazvin province. -Iranian Journal of Forest and Poplar Research 17(3): 475-487.

[13] Rada, F., Azocar, A., Gonzalez, J., Briceno, B. (1998): Leaf gas exchange in Espeletia schultzii Wedd, a giant caulescent rosette species, along an altitudinal gradient in the Venezuelan Andes. -Acta Oecologica 19: 73-79.

[14] Ramazani, E., Azizi, P., Akbarinia, M., Pourmajidian, M.R. (2000): Study of soil properties and compeer plants with Acer cappadocicum in west of Mazandaran forests. National conference management of northern forests and sustainable development, Ramsar, Iran. 1-8.

[15] Rikhari, H.C., Adhikari, B.S. (1998): Population structure and protective value of temperate forests in a part of Central Himalaya. -Journal of Sustainability Forestry 7 (3/4): 5-21.

[16] Sabeti, H. (2008): Forests, Trees and Shrubs of Iran.- Publication of Yazd University.

[17] SadatiS.E., Mostafanejad, S.R. (2009): Qualitative and quantitative investigation on plantations of lime tree (Tilia platyphyllos) and coliseum maple (Acer cappadocicum) in Chamestan region, northern Iran. -Iranian Journal of Forest and Poplar Research 16 (3): 408-418.

[18] Sefidi, K., Marvie-Mohadjer, M.R., Etemad, V., Copenheaver, C.A. (2011): Stand characteristics and distribution of a relict population of Ironwood (Parrotia persica C.A. Meyer) in northern Iran. -Flora 206: 418-422.

[19] Sharafieh, H., Sagheb-Talebi, Kh. (2012): Investigation on some silvicultural and habitat characteristics of Quercus macranthera F.\& M at Semnan Province if Iran. -Iranian Journal of Forest and Poplar Research 20(3): 429-443.

[20] Zhang, S.B., Zhou, Z.K., Hu, H., Xu, K., Yan, N., Li, S.Y. (2005): Photosynthetic performances of Quercus pannosa vary with altitude in the Hengduan Mountains, southwest China. -Forest Ecology and Management, 212: 291-301.

[21] Zobeyri, M. (2002): Forest Biometry. -Tehran University Press, Tehran. 